\title{
AKTIVITAS TABIR SURYA EKSTRAK DAUN CEMPEDAK (ARTOCARPUS CHAMPEDEN SPRENG)
}

\author{
Whenny, Rolan Rusli, Laode Rijai \\ Laboratorium Penelitian dan Pengembangan FARMAKA TROPIS, \\ Fakultas Farmasi Universitas Mulawarman, Samarinda, Kalimantan Timur \\ email: cicilia.whenny@yahoo.com
}

\begin{abstract}
Cempedak leaf (Artocarpus champeden Spreng) has potential sunscreen activity which contains flavonoids that has photoprotection properties to absorb ultraviolet light. This study aims to determine the sunscreen categories of the extract from leaves of cempedak. The measurement results showed that the sunscreen activity of cempedak leaves extract based on $\%$ Te has the category as sunblock, extra protection and suntan standard, while sunscreen activity of cempedak leaves extract based on \% Tp has the category as sunblock.
\end{abstract}

Keywords: potential sunscreen, cempedak leaves, percentage of erythema transmission, percentage of pigmentation transmission.

\begin{abstract}
Abstrak
Daun cempedak (Artocarpus champeden Spreng) memiliki potensi beraktivitas sebagai tabir surya karena mengandung senyawa flavonoid yang memiliki sifat fotoprotektif sehingga mampu menyerap sinar ultraviolet. Penelitian ini bertujuan untuk mengetahui kategori aktivitas tabir surya dari ekstrak daun cempedak. Hasil pengukuran menunjukkan bahwa aktivitas tabir surya ekstrak daun cempedak berdasarkan persentase transmisi eritema terdiri atas kategori sunblock, proteksi ekstra dan suntan standar, sedangkan aktivitas tabir surya ekstrak daun cempedak berdasarkan persentase transmisi pigmentasi termasuk kategori sunblock.
\end{abstract}

Kata kunci: aktivitas tabir surya, daun cempedak, persentase transmisi eritema, persentase transmisi pigmentasi.

\section{PENDAHULUAN}

Sinar ultraviolet hanya merupakan sebagian kecil dari spektrum sinar matahari tetapi sinar ini paling berbahaya bagi kulit karena reaksi-reaksi yang ditimbulkannya berpengaruh buruk terhadap kulit manusia baik berupa perubahan-perubahan akut seperti eritema, pigmentasi dan fotosensitivitas, maupun efek jangka panjang berupa penuaan dini dan kanker kulit. Pencegahan efek buruk paparan sinar matahari salah satunya dapat dilakukan dengan penggunaan tabir surya. Tabir surya digunakan untuk melindungi kesehatan kulit manusia dari pengaruh negatif UV akibat radiasi sinar matahari [1].

Perkembangan tabir surya saat ini lebih mengarah kepada pemanfaatan bahan-bahan alam dengan alasan bahan alam lebih murah, mudah didapatkan 
serta diyakini tidak memiliki efek samping yang berbahaya bila dibandingkan dengan bahan-bahan kimia sintesis. Penggunaan bahan alam yang dapat menurunkan radiasi sinar matahari dan meningkatkan perlindungan terhadap efek negatif radiasi sinar matahari pada kulit menjadi fokus dalam beberapa penelitian [2].

Daun cempedak merupakan salah satu daun yang sering dimanfaatkan secara tradisional oleh masyarakat Kalimantan di Indonesia sebagai bedak dingin dan penghilang flek hitam pada wajah. Ekstrak kasar dan fraksi etil asetat daun cempedak memiliki aktivitas antioksidan dan mengandung metabolit sekunder berupa flavonoid [3], sehingga diduga aktivitas tabir surya tersebut dapat bersumber dari senyawa flavonoid. Senyawa fenolik yang terdapat dalam tumbuhan berfungsi melindungi jaringan tanaman terhadap kerusakan akibat radiasi sinar matahari. Senyawa fenolik khususnya golongan flavonoid mempunyai potensi sebagai tabir surya karena adanya gugus kromofor yang mampu menyerap sinar UV sehingga mengurangi intensitasnya pada kulit [4]. Penelitian ini dilakukan untuk menguji potensi tabir surya pada ekstrak daun cempedak (Artocarpus champeden Spreng) secara in vitro menggunakan spektrofotometer UV-Vis dengan metode pengukuran $\%$ transmisi eritema dan $\%$ transmisi pigmentasi kemudian potensi tabir surya dikategorikan berdasarkan tabel 1 .

Tabel 1. Kategori Penilaian Aktivitas Tabir Surya [5]

\begin{tabular}{ccc}
\hline \multirow{2}{*}{ Kategori } & \multicolumn{2}{c}{$\%$ Transmisi } \\
\cline { 2 - 3 } & Eritema & Pigmentasi \\
\hline Sunblock & $<1 \%$ & $3-40 \%$ \\
Proteksi ekstra & $1-6 \%$ & $42-86 \%$ \\
Suntan standar & $6-12 \%$ & $45-86 \%$ \\
Fast tanning & $10-18 \%$ & $45-86 \%$ \\
\hline
\end{tabular}

\section{METODE PENELITIAN}

\section{Bahan}

Daun cempedak segar berwarna hijau yang diambil di kebun sebanyak $3,17 \mathrm{~kg}$, kemudian dicuci bersih, dirajang dan dikering anginkan hingga menjadi simplisia kering berwarna coklat. Aquades, metanol, etil asetat dan $n$ heksan sebagai pelarut.

\section{Peralatan}

Seperangkat alat gelas yang terdapat di laboratorium, rotary evaporator, spektrofotometri UV-Vis double beam (Dynamica Halo DB-20S), dantimbangan analitik.

\section{Prosedur Penelitian}

\section{Penyiapan Sampel}

Simplisia kering dimasukkan ke dalam bejana maserasi, lalu direndam dengan metanol sampai semua simplisia terendam dan didiamkan selama 4 hari sambil sesekali diaduk, kemudian filtrat disaring. Residu direndam kembali dengan metanol dan dibiarkan selama 3 hari dan disaring kembali, lalu filtrat yang terkumpul dipekatkan dengan rotary evaporator sehingga diperoleh ekstrak kental, yang selanjutnya di kering anginkan hingga diperoleh ekstrak kasar. Ekstrak kasar kemudian difraksinasi dengan cara dilarutkan dalam $50 \mathrm{~mL}$ aquades, dimasukkan ke dalam labu pisah dan ditambahkan dengan pelarut $n$ - 
heksan sebanyak $50 \mathrm{~mL}$ kemudian di gojog. Setelah tampak pemisahan, lapisan bawah di keluarkan (larut air) dan lapisan atas (fraksi $n$-heksan) dikeluarkan dan diuapkan pelarutnya. Kemudian lapisan bawah (larut air) ditambahkan dengan pelarut kembali dan digojog hingga lapisan atas tetap bening. Setelah bening kemudian $n$-heksan diganti dengan etil asetat dan prosedur fraksinasi diulang kembali hingga diperoleh fraksi etil asetat.

Ekstrak kasar dan fraksi etil asetat daun cempedak dibuat dalam konsentrasi 500 ppm sebanyak $100 \mathrm{~mL}$ sebagai larutan stok, kemudian masingmasing larutan stok dibuat ke dalam beberapa variasi konsentrasi. Konsentrasi ekstrak kasar daun cempedak yaitu 100 , $150,200,250,300$ dan 350 ppm, sedangkan konsentrasi fraksi etil asetat daun cempedak yaitu 50, 75, 100, 150, 200, dan 250 ppm semua dalam $25 \mathrm{~mL}$.

\section{Pengujian Aktivitas Tabir Surya Sampel \\ $\begin{array}{ccr}\text { Masing-masing } & \text { konsentrasi } \\ \text { diukur } & \text { absorbansinya } & \text { dengan }\end{array}$ menggunakan spektrofotometer UV-Vis pada panjang gelombang 292,5-372,5 nm dengan interval $5 \mathrm{~nm}$ (3 kali replikasi).}

\section{Perhitungan \% Te dan \% Tp}

Berdasarkan nilai absorbansi (A) yang diperoleh maka nilai transmisi dapat dihitung dengan menggunakan rumus:

$$
A=-\log T
$$

Persentase transmisi eritema dan persentase transmisi pigmentasi dihitung dengan menggunakan rumus:

$$
\begin{aligned}
& \% \text { Transmisi Eritema }=\frac{E e}{\sum F e}=\frac{\sum(T \times F e)}{\sum F e} \\
& \% \text { Transmisi Pigmentasi }=\frac{E p}{\sum F p}=\frac{\sum(T \times F p)}{\sum F p}
\end{aligned}
$$

Keterangan :

Te : Transmisi eritema

Fe : Fluks eritema yang nilainya pada panjang gelombang tertentu
Ee : Banyaknya fluks eritema yang diteruskan oleh tabir surya

Tp : Transmisi pigmentasi

Fp : Fluks pigmentasi yang nilainya pada panjang gelombang tertentu

Ep : Banyaknya fluks pigmentasi yang diteruskan oleh tabir surya.

\section{HASIL DAN PEMBAHASAN}

Aktivitas tabir surya ekstrak kasar dan fraksi etil asetat daun cempedak yang dimaksud adalah pengelompokkan aktivitas tabir surya ke dalam 4 kategori yaitu sunblock, proteksi ekstra, suntan standar atau fast tanning. Penentuan kategori tabir surya ini berdasarkan pada perhitungan nilai $\% \mathrm{Te}$ dan $\%$ Tp dari berbagai konsentrasi. Nilai absorbansi hasil pengukuran masingmasing konsentrasi dikonversi menjadi nilai transmitan, dimana semakin kecil nilai transmitan maka semakin banyak sinar yang diserap oleh sampel sehingga aktivitas tabir surya semakin baik. Hasil analisis data tentang pengelompokkan aktivitas tabir surya ekstrak kasar dan fraksi etil asetat daun cempedak ditunjukkan pada tabel 2 dan tabel 3. Berdasarkan tabel tersebut kategori aktivitas tabir surya ekstrak daun cempedak hanya ada 3 yaitu sebagai sunblock, proteksi ekstra dan suntan standar. Pengkategorian aktivitas tabir surya dibagi menjadi kategori aktivitas tabir surya berdasarkan nilai $\%$ Te dan $\%$ Tp.

Suntan standar adalah kategori
penilaian aktivitas tabir surya dimanasuatu bahan mampu mencegah sengatan sinar matahari dengan mengabsorbsi $95 \%$ atau lebih radiasi UV B [7]. Kategori suntan standar menyerap sebagian besar sinar UV B dan menyerap sedikit sinar UV A sehingga dapat menyebabkan pigmentasi tanpa terjadinya eritema. Suntan standar mampu mencegah terjadinya eritema pada kulit normal atau jenis kulit yang tidak sensitif [6]. Aktivitas tabir surya ekstrak kasar daun cempedak sebagai 
suntan standar ditunjukkan pada tabel 2 yaitu berdasarkan \% Te terdapat pada konsentrasi $150 \mathrm{ppm}$, sedangkan pada fraksi etil asetat berdasarkan \% $\mathrm{Te}$ diperlukan konsentrasi lebih kecil yaitu 75 ppm untuk menghasilkan kategori tabir surya sebagai suntan standar.

Tabel 2. Profil Tabir Surya Ekstrak Kasar Daun Cempedak

\begin{tabular}{ccccc}
\hline Konsentrasi & $\%$ Te & Profil Tabir Surya & $\%$ Tp & Profil Tabir Surya \\
\hline 100 & 22,2912 & - & 17,1891 & Sunblock \\
150 & 10,2514 & Suntan standar & 6,9246 & Sunblock \\
200 & 5,2116 & Proteksi ekstra & 3,1782 & Sunblock \\
250 & 2,6723 & Proteksi ekstra & 1,4734 & Sunblock \\
300 & 1,3744 & Proteksi ekstra & 0,6782 & Sunblock \\
350 & 0,7730 & Sunblock & 0,3536 & Sunblock \\
\hline
\end{tabular}

Tabel 3. Profil Tabir Surya Fraksi Etil Asetat Daun Cempedak

\begin{tabular}{ccccc}
\hline Konsentrasi & $\% \mathrm{Te}$ & Profil Tabir Surya & $\% \mathrm{Tp}$ & Profil Tabir Surya \\
\hline 50 & 22,1636 & - & 21,2371 & Sunblock \\
75 & 11,1679 & Suntan standar & 10,5464 & Sunblock \\
100 & 5,6172 & Proteksi ekstra & 5,1994 & Sunblock \\
150 & 1,3976 & Proteksi ekstra & 1,2602 & Sunblock \\
200 & 0,3435 & Sunblock & 0,3017 & Sunblock \\
250 & 0,1087 & Sunblock & 0,1052 & Sunblock \\
\hline
\end{tabular}

Proteksi ekstra adalah kemampuan ekstrak sebagai bahan tabir surya yang memberikan perlindungan terhadap eritema dengan mengabsorbsi kurang dari $85 \%$ radiasi sinar UV B serta mencegah terjadinya pigmentasi. Kemampuan bahan pada kategori ini akan menghasilkan sedikit eritema tanpa rasa sakit [7]. Kategori proteksi ekstra tabir surya digunakan untuk melindungi jenis kulit yang sensitif [6]. Berdasarkan tabel 2, konsentrasi ekstrak kasar daun cempedak yang diperlukan untuk mendapatkan aktivitas tabir surya sebagai proteksi ekstra berdasarkan nilai \% Te adalah pada rentang konsentrasi 200 sampai 300 ppm, sedangkan pada tabel 3 berdasarkan \% Te pada fraksi etil asetat diperlukan konsentrasi lebih kecil yaitu 100 sampai 150 ppm.

$$
\text { Sunblock merupakan }
$$

kemampuan ekstrak untuk memproteksi secara total kulit yang sangat sensitif terhadap sinar UV A dan UV B [6]. Aktivitas tabir surya ekstrak sebagai sunblock mampu menghalangi paparan sinar UV ke dalam kulit sehingga melindungi kulit dari terjadinya eritema dan pigmentasi. Berdasarkan tabel 2 menunjukkan konsentrasi 350 ppm ekstrak kasar dari nilai \% Te memiliki kategori sunblock, sedangkan kategori sunblock dari \% Tp ekstrak kasar ditunjukkan pada konsentrasi 100-350 ppm. Fraksi etil asetat daun cempedak pada tabel 3 merupakan sampel paling baik karena nilai \% Te pada konsentrasi 200 ppm telah menunjukkan aktivitas tabir surya sebagai sunblock, sedangkan kategori sunblock berdasarkan nilai \% Tp terdapat pada konsentrasi 50-250 ppm. Semua konsentrasi ekstrak kasar dan fraksi etil asetat mampu memproteksi secara total UV A yang dapat diketahui berdasarkan nilai $\% \mathrm{Tp}$. 
Secara umum semua ekstrak aktif sebagai tabir surya, hal ini disebabkan oleh adanya senyawa metabolit sekunder. Senyawa metabolit sekunder yang dapat berperan sebagai tabir surya antara lain adalah flavonoid, fenolik dan tanin [8]. Untuk fraksi etil asetat daun cempedak memiliki profil tabir surya lebih baik daripada ekstrak kasar daun cempedak karena adanya kandungan flavonoid [3].

\section{KESIMPULAN}

Profil tabir surya ekstrak kasar daun cempedak berdasarkan \% Te adalah suntan standar, proteksi ekstra dan sunblock, dengan konsentrasi berturutturut $150 \mathrm{ppm}, 200-300 \mathrm{ppm}$, dan 350 ppm, sedangkan berdasarkan \% Tp adalah sunblock dengan konsentrasi 100$350 \mathrm{ppm}$. Profil tabir surya fraksi etil asetat daun cempedak berdasarkan \% Te adalah suntan standar, proteksi ekstra dan sunblock, dengan konsentrasi berturutturut 75 ppm, 100-150 ppm, dan 200-250 ppm, sedangkan berdasarkan \% Tp adalah sunblock dengan konsentrasi 50$250 \mathrm{ppm}$.

\section{DAFTAR PUSTAKA}

1. Satiadarma, H. dan Suyoto. 1986. Kesehatan Kulit dan Kosmetika. Andy Offset. Yogyakarta.
2. Tabrizi, H., S. A. Mortazavi and M. Kamalinejad. 2003. An In Vitro Evaluation of Various Rosa damascene Flower Extracts as a Natural Antisolar Agent. International Journal of Cosmetic Science. 25. (6)259-265.

3. Rahmawati, Dwi. 2013. Uji Aktivitas Antioksidan dan Identifikasi Metabolit Sekunder Batang dan Daun Cempedak (Artocarpus champeden Spreng). Skripsi. Fakultas Farmasi Universitas Mulawarman. Samarinda.

4. Halliwel, B., and Gutteridge, J. M. C. 1999. Free Radical in Biology and Medicine. Oxford University Press. New York.

5. Balsam, M. S. dan Sagarin, E. 1974. Cosmetiscs Science and Technology Vol III. Wiley Interscience. New York.

6. Cumpelik, B. S. 1972. Analitical Procedures and Evaluation of Sunscreens. Journal of the Society of Cosmetics Chemistry. 25. (3) 333345.

7. Wilkinson, J. B dan Moore, R. J. 1982. Harry's Cosmeticology ( $7^{\text {th }}$ edition). Chemical Publishing Company. New York.

8. Suryanto, E. 2012. Fitokimia Antioksidan. Penerbit Putra Media. Surabaya. 